\title{
PENGARUH MODEL PEMBELAJARAN INQUIRY TRAINING BERBANTUAN MACRO MEDIA FLASHTERHADAP HASIL BELAJAR SISWA DI KELAS XI SMA NEGERI10 MEDAN T.P. 2014/2015
}

\author{
Merry Dame Christiani Panjaitan dan Sondang R.Manurung \\ Jurusan Fisika FMIPA Universitas Negeri Medan \\ Jalan Willem Iskandar Pasar V Medan, Sumatera Utara \\ e_mail:merrydame7@gmail.com
}

\begin{abstract}
ABSTRAK
Penelitian ini bertujuan untuk mengetahui pengaruh penerapan model pembelajaraninquiry training berbantuan macromediaflash terhadap hasil belajar siswadan aktivitas siswa selama proses pembelajaran pada materi fluida statis di kelas XI SMA 10 Medan. Jenis penelitian ini adalah quasi eksperiment. Populasi dalam penelitian adalah seluruh siswa kelas XI IPA SMA Negeri 10 Medan yang terdiri dari 4kelas. Pengambilan sampel dilakukan dengan cara cluster random sampling, dan terpilih kelas XI IPA3 sebagai kelas eksperimen dan kelas XI IPA-4 sebagai kelas kontrol. Instrumen yang digunakan adalah tes berbentuk pilihan berganda dan lembar observasi. Hasil penelitian diperoleh nilai rata-rata pretes kelas eksperimen adalah 38 dan kelas kontrol adalah 37. Nilai rata-rata postes kelas eksperimen adalah 73,57 dan kelas kontrol adalah 63. Peningkatan seluruh aktivitas siswa kelas eksperimen termasuk dalam kategori sedang. Berdasarkan hasil analisis uji hipotesis, diperoleh hasil belajar siswa akibat pengaruh model pembelajaran inquiry training berbantuan macromediaflash lebih baik daripada pembelajaran konvensional pada materi fluida statis.
\end{abstract}

Kata kunci: model pembelajaran, inquiry training, macromediaflash, hasil belajar

\begin{abstract}
The purpose of research is to knoweffect application learning model of inquiry training assisted macromediaflashtoward the result of student learning and learning activities of students during the learning process in the subject static fluid of class XI SMA 10 Medan. This research is a quasi experiment. The population is all of students class XI SMA IPA Negeri 10 Medan consisting of 4 classes. Sampling was done by cluster random sampling XI IPA-3 as the experiments class and XI IPA-4 as the control class. The instruments of resulting in the form of multiple-choice tests and observation sheets. Results are obtained the average value of pretest of learning result is 38 on experimental class and control class 37 . The average value of posttest of learning result is 73,57 on experimental class and control class 63. Thhere are increasing of learning actvity for te
\end{abstract}


experimental class on te medium criteria. Based on the analysis of the hypotesis testing, the results of student learning for the student are teached by the learning model of inquiry training assisted macromediaflash is better than conventional learning on material static fluid.

\section{Keywords : learning model, inquiry training, macromediaflash, learning results}

\section{PENDAHULUAN}

Pendidikan adalah investasi manusia memperoleh pengakuan dari banyak kalangan ahli. Kemajuan suatu bangsa sangat ditentukan oleh kualitas sumber daya manusia (SDM). Kualitas SDM sangat bergantung pada kualitas pendidikan. Oleh karena itu, pengembangan dan pembangunan SDMmerupakan salah satu syarat yang penting bagi pembangunan (Kunandar, 2007:10).

Menurut Slameto (2010:1)

dalam era industrialisasi, bangsa Indonesia membulatkan tekadnya untuk mengembangkan budaya belajar yang menjadi prasyarat berkembangnya ilmu pengetahuan dan teknologi (IPTEK). Hal ini dapat terlihat dengan semakin pesatnya perkembangan IPTEK sekarang ini.fisika ditempatkan sebagai salah satu mata pelajaran yang penting karena salah satu syarat penguasaan IPTEK berhubungan dengan ilmu pengetahuan alam (IPA).

Menurut Trianto (2011:5), kurangnya hasil belajar peserta didik yang disebabkan dominannya proses pembelajaran konvensional. Pada pembelajaran ini, suasana kelas cenderung teacher-centered sehingga siswa menjadi pasif. Di sisi lain, guru juga dominan menggunakan metode ceramah dan penugasan serta kurangnya memanfaatkan media dalam pembelajaran, sehingga banyak siswa yang menyatakan bahwa pelajaran fisika itu merupakan pelajaran yang sulit untuk dipahami dan membosankan.

Hasil studi pendahuluan yang dilakukan peneliti (Panjaitan, 2015) di SMA Negeri 10 Medan dengan melakukan wawancara kepada salah satu guru bidang studi fisika, diperoleh data hasil belajar fisika masih rendah.Jika dilihat dari kriteria paling rendah untuk menyatakan peserta didik mencapai KKM (Kriteria Ketuntasan Minimal) pada mata pelajaran fisika yang ditetapkan di sekolah adalah 75, tetapi rata-rata hanya 10 orang siswa saja di tiap kelas yang mampu mencapai nilai di atas 75 dan yang lainnya masih di bawah 75 . Kenyataan tersebut didukung oleh angket yang telah diberikan kepada siswa SMA Negeri 10 Medan. Berdasarkan hasil angket pada salah satu kelas, diperoleh data bahwa dari 35 siswa, beberapa siswa mengatakan bahwa fisika itu sulit karena guru lebih dominan menjelaskan menggunakan rumus,kurang menarikkarena guru lebih dominan menggunakan metode ceramahuntuk kegiatan belajar mengajar fisika, siswa cenderung pasif dalam proses belajar mengajar, dan menginginkan belajar sambil berdiskusi serta melakukan praktikum ataupun demonstrasi.

Kemampuan belajar manusia dapat muncul dengan diawali rasa keingintahuan. Ketidakpastian muncul ketika mengalami sesuatu yang baru, mengejutkan, tidak layak, 
atau kompleks. Hal ini menimbulkan rangsangan yang tinggi dalam sistim saraf. Respon manusia ketika menghadapi suatu ketidakpastian inilah yang disebut dengan curiosity atau rasa ingin tahu.Salah satu model pembelajaran yang mengarahkan siswa, khususnya siswa SMA Negeri 10 Medan untuk menciptakan rasa ingin tahu (curiosity)mengenai peristiwa dan fenomena alam disekitarnya serta mengajak siswa untuk menyelidiki solusi dari fenomena itu adalah model pembelajaran inquiry training. Menurut Uno (2008:14) model pembelajaran inquiry training adalah model yang bertujuan untuk melatih kemampuan siswa dalammeneliti, menjelaskan fenomena, dan memecahkan masalah secara ilmiah.Model ini meyakinkan siswa bahwa ilmu bersifat tentatif dan dinamis, karena ilmu berkembang terus-menerus.Joyce et all. (2009:213)menyatakan bahwa model pembelajaran ini menawarkan strategi-strategi penelitian, nilainilai, dan sikap-sikap yang penting dalam ranah penelitian, yang meliputi: (1) keterampilan mengolah (mengobservasi, mengumpulkan, dan mengolah data; mengidentifikasi dan mengontrol variabel-vatiabel; merumuskan dan menguji hipotesis dan penjelasan; menarik kesimpulan); (2) pembelajaran aktif, mandiri; (3) pengungkapan verbal; (4) toleran pada ambiguitas; ketekunan; (5) berpikir logis; (6) sikap bahwa semua pengetahuan bersifat tentatif.

Harapan untuk hasil belajar yang lebih baik dan meninjau fisika sebagaifondasi IPTEK, dapat dilakukan dengan model pembelajaraninquiry trainingdisertai dengan media komputer yang menggunakan aplikasi macro media flash. Macro media flash adalah sebuah program aplikasi profesional untuk menggambar grafis dan animasi berupa vektor dan gambar (Simanjuntak, 2014:29).

Berdasarkan uraian di atas, adapun tujuan penelitian ini adalah untuk untuk mengetahui perbedaan akibat pengaruh penerapan model pembelajaran inquiry training berbantuan macro media flash terhadap hasil belajar siswa serta untuk mengetahui aktivitas siswa selama proses pembelajaran pada materi pokok fluida statis di kelas XI SMA 10 Medan.

\section{METODE PENELITIAN}

Populasi dalam penelitian ini adalah siswa kelas XI IPA SMA Negeri 10 Medan yang terdiri dari 4 (empat) kelas.Teknik pengambilan sampel dilakukan dengan cara teknik sampel kelas acak (cluster random sampling). Variabel dalam penelitian ini terdiri atas variabel bebas yaitumodel pembelajaran inquiry training berbantuan animasi macro media flash dan variabel terikat yaitu adalah hasil belajar siswa pada materi pokok fluida statis.

Rancangan penelitian ini quasi eksperiment dengan desain: control group pretest - postest design. Dengan demikian rancangan penelitian ini dapat dilihat pada Tabel 1.

Tabel 1.Desain Penelitian tipe Two Group (Pre-Test dan Post-test)

\begin{tabular}{|l|c|c|c|}
\hline Kelas & $\begin{array}{c}\text { Pre- } \\
\text { Test }\end{array}$ & Perlakuan & $\begin{array}{c}\text { Post- } \\
\text { Test }\end{array}$ \\
\hline Eksperimen & $\mathrm{T}_{1}$ & $\mathrm{X}$ & $\mathrm{T}_{2}$ \\
Kontrol & $\mathrm{T}_{1}$ & $\mathrm{Y}$ & $\mathrm{T}_{2}$ \\
\hline
\end{tabular}


Keterangan:

$\begin{aligned} \text { Pre-Test }= & \text { Test yang dilakukan } \\ & \text { kepada kelas } \\ & \text { eksperimen dan kontrol } \\ & \text { sebelum perlakuan } \\ & \text { model pembelajaran } \\ \text { Post }- \text { Test }= & \text { Test yang dilakukan } \\ & \text { kepada kelas } \\ & \text { eksperimen dan kontrol } \\ & \text { setelah perlakuan model } \\ & \text { pembelajaran }\end{aligned}$

$\mathrm{T}_{1} \quad=$ Pemberian pretes

$\mathrm{T}_{2}=$ Pemberian postes

Hasil pretes yang diolah dengan uji normalitas dan uji kesamaan rata-rata (uji t) untuk menentukan apakah data berdistribusi normal dan untuk mengetaui kesamaan kemampuan awal siswa pada kedua kelas sebelum diberi perlakuan yang berbeda. Selanjutnya, kedua kelas diberi perlakuan dengan menerapkan model pembelajaran inquiry training berbantuan macromediaflashpada kelas eksperimen dan pembelajaran konvensional pada kelas kontrol.

Sebelum digunakan dalam penelitian yang sebenarnya, tes yang disusun terlebih dahulu divalidkan oleh validator.Dalam hal ini validitas yang dipakai pada tes hasil belajar adalah validitas isi.Validitas isi yaitu menyesuaikan soal tes dengan berpedoman pada kurikulum dengan materi fluida statis.

Selama proses pembelajaran berlangsung, aktivitas siswa diamati baik di kelas eksperimen maupun di kelas kontrol dengan menggunakan penilaian aktivitas yang sama. upaya ini dilakukan untuk mengetaui peningkatan aktivitas siswa selama proses pembelajaran. Perhitungan yang digunakan yaitu dengan indeks gain.Peningkatan yang terjadi sebelum dan sesudah pembelajaran menurut Meltzer dihitung dengan rumus g-faktor (N-Gain) dengan rumus:

$$
g=\frac{S_{\text {pos }}-S_{\text {pre }}}{S_{\text {maks }}-S_{\text {pre }}}
$$

Kriteria tingkat gain menurut Hake yang ditunjukkan pada Tabel 2 .

Tabel 2.Kriteria Tingkat Gain

\begin{tabular}{|c|c|}
\hline $\mathbf{g}$ & Keterangan \\
\hline $\mathrm{g}>0,7$ & Tinggi \\
$0,3<\mathrm{g} \leq 0,7$ & Sedang \\
$\mathrm{g} \leq 0,3$ & Rendah \\
\hline
\end{tabular}

Berdasarkan perlakuan yang berbeda dan penilaian aktivitas yang sama selanjutnya dilakukan postes untuk mengetahui hasil belajar kedua kelas. Dari hasil postes, dilakukan kembali uji normalitas dan uji kesamaan rata-rata (uji t) untuk menentukan apakah data normal dan terdapat perbedaan yang signifikan antara hasil belajar kedua kelas yang menunjukkan ada atau tidaknya pengaruh model pembelajaran inquiry trainingterhadap hasil belajar siswa.

Pada analisis data hasil belajar siswa digunakan uji t untuk mengetahui pengaruh dari suatu perlakuan yaitu model pembelajaran inquiry training berbantuan macromediaflash terhadap hasil belajar siswa. Hipotesis yang diuji berbentuk:

Keterangan :

$$
\begin{aligned}
& H_{o}: \overline{\mu_{1}}=\overline{\mu_{2}} \\
& H_{a}: \overline{\mu_{1}}>\overline{\mu_{2}}
\end{aligned}
$$

$\overline{\mu_{1}}=\overline{\mu_{2}}:$ tidak ada perbedaan hasil belajar siswa yang diajarkan dengan modelpembelajaraninqui ry trainingberbantuan macromediaflashdengan yang diajarkan secara pembelajaran konvensional pada materi fluida statis. 


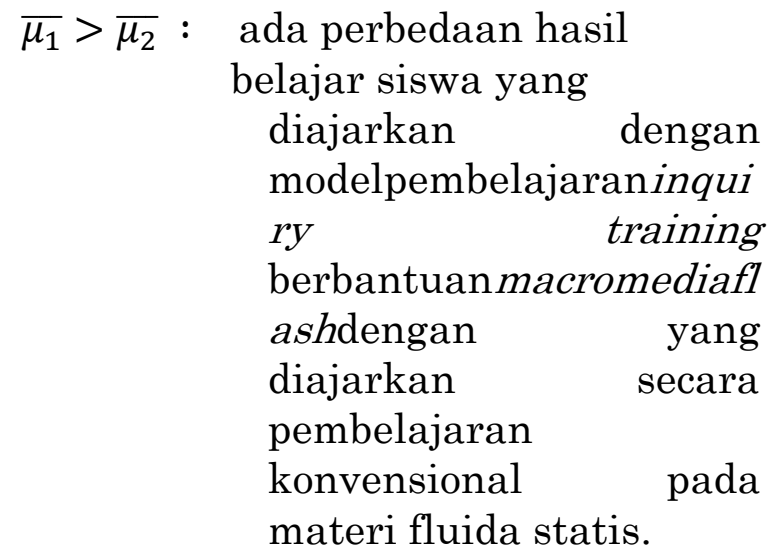

Jika analisis data menunjukkan bahwa, $t>t_{1-\alpha}$ atau nilai $\mathrm{t}$ hitung yang diperoleh lebih dari $t_{1-\alpha}$, maka hipotesis Ho ditolak dan $\mathrm{Ha}$ diterima. Dapat diambil kesimpulan hasil belajar siswa pada kelas eksperimen lebih besar daripada hasil belajar siswa kelas kontrol, maka model inquiry training berbantuan

macromediaflashberpengaruh

terhadap hasil belajar siswa.

\section{HASIL DAN PEMBAHASAN Hasil Penelitian}

Penelitian diawali dengan memberikan pretes terhadap kedua sampel dengan jumlah soal 20 soal dalam bentuk pilihan berganda yaitu pada kelas eksperimen dan keas kontrol. Berdasarkan data penelitian diperoleh nilai rata-rata pretes siswa pada kelas eksperimen sebelum diberi perlakuan adalah 38 dengan standar deviasi 10,58, sedangkan nilai rata-rata pretes siswa pada kelas kontrol adalah 37 dengan standar deviasi 10,86.

Kedua kelas diberi perlakuan yang berbeda yaitu pada kelas eksperimen diberi perlakuan menggunakan model pembelajaran inquiry training berbantuan macromediaflash, sedangkan kelas kontrol diberi perlakuan dengan menggunakan

pembelajaran konvensional.

Selama proses pembelajaran berlangsung aktivitas siswa juga diamati. Aspek aktivitas yang diamati antara lain: memberikan jawaban,mendengarkan penjelasan guru, memberikan pertanyaan, melakukan diskusi,menjawab soal, dan memberikan kesimpulan materi pelajaran. Observasi dilakukan selama kegiatan belajar mengajar yang terdiri dari tiga kali pertemuan yang dilakukan oleh seorang observer yaitu rekan sejawat. Dalam penelitian ini, peningkatan terjadi setiap pertemuan pembelajaran dihitung dengan rumus N-Gain dapat dilihat pada Gambar 1.

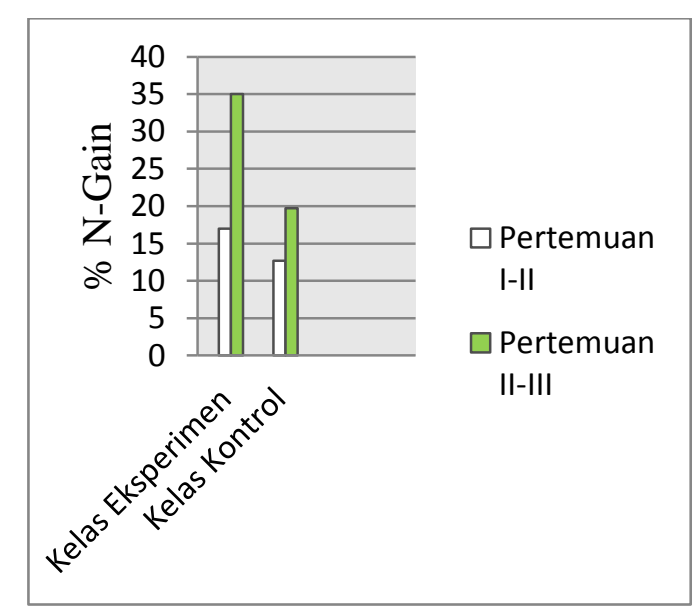

Gambar 1. Peningkatan Aktivitas pada Kelas Eksperimen dan Kelas Kontrol

Berdasarkan Gambar 1. dapat dilihat rata-rata peningkatan aktivitas belajar siswa di kelas eksperimen dengan menerapkan model pembelajaran inquiry trainingberbantuan

macromediaflashdiperoleh \%N-gain aktivitas pada pertemuan I-II dan pertemuan II-III masing-masing $17 \%$ dan 35\%dan pada kelas kontrol dengan menerapkan pembelajaran 
konvensional diperoleh \%N-gain aktivitas pada pertemuan I-II dan pertemuan II-III masing-masing 12,7\% dan 19,7\%.Dari data diperoleh bahwa rata-rata peningkatan aktivitas belajar siswa di kelas eksperimen lebih tinggi daripada kelas kontrol. Hal ini menunjukkan penerapan model pembelajaran yang dilakukan di kelas eksperimen lebih baik daripada kelas kontrol.

Penerapan perlakuan yang berbeda pada kedua kelas selanjutnya diberikan postes dengan soal yang sama dengan soal pretes. Hasil yang diperoleh adalah nilai rata-rata postes kelas eksperimen setelah diterapkan model pembelajaran inquiry training berbantuan macromediaflash sebesar 73,57 dengan standar deviasi 10,61 sedangkan rata-rata postes kelas kontrol setelah diterapkan pembelajaran konvensional sebesar 63 dengan standar deviasi 10,66.

Hasil uji normalitas untuk kedua sampelmenunjukkan bahwa kedua kelas berdistribusi normal dimana $\mathrm{L}_{\text {hitung }}<\mathrm{L}_{\text {tael }}$ dan berasal dari populasi yang homogen. Hasil uji hipotesis untuk postes menggunakan uji $\mathrm{t}$ pada taraf signifikan $\alpha=0,05$ diperoleh $t_{\text {hitung }}>t_{\text {tabel }}(4,065>1,669)$ yang berarti bahwa ada perbedaan yang signifikan akibat pengaruh model pembelajaran inquiry training berbantuan macromediaflash terhadap hasil belajar siswa pada materi fluida statis.

Penilaian afektif berkenaan dengan sikap siswa selama kegiatan belajar mengajar. Aspek afektif yang dinilai antara lain: rasa ingin tahu, bekerja sama, kritis, dan menanggapi pendapat orang lain. Peningkatan afektif siswa kelas eksperimen dan kelas kontrol dapat dilihat pada Gambar 2.

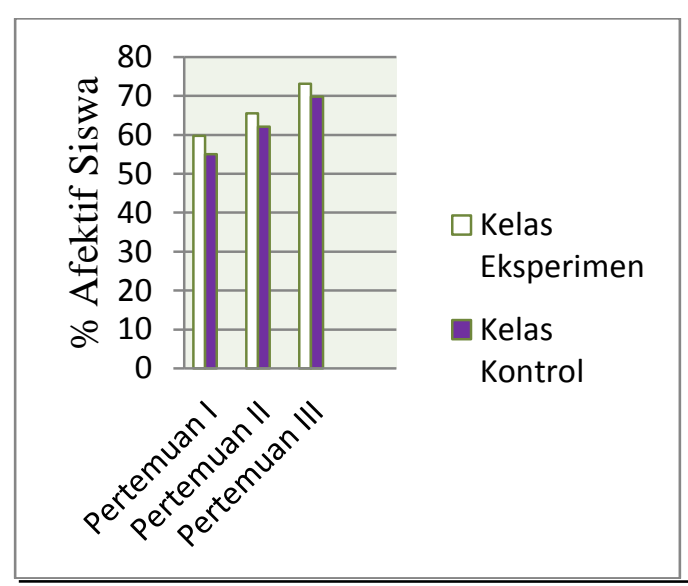

Gambar 2.Penilaian Afektif Siswa di Kelas Eksperimen dan Kontrol

Gambar 2.menunjukkannilai rata-rata persentase perkembangan afektif siswa di kelas eksperimen selama menerima pembelajaran dengan menggunakan model pembelajaran

trainingberbantuan

macromediaflashadalah $\quad 66,11 \%$ dengan kriteria aktif. Rata- rata persentase perkembangan afektifsiswa di kelas kontrol selama menerima pembelajaran dengan menggunakan pembelajaran konvensional yaitu $62,3 \%$ dengan kriteria cukup aktif.

Hasil belajar psikomotorik tampak dalam bentuk keterampilan (skill) dan kemampuan bertindak siswa. Aspek psikomotorik yang dinilai antara lain: merangkai percobaan, melakukan percobaan, mengolah data percobaan, dan menyimpulkan hasil percobaan. Peningkatan afektif siswa kelas eksperimen dapat dilihat pada Gambar 3. 


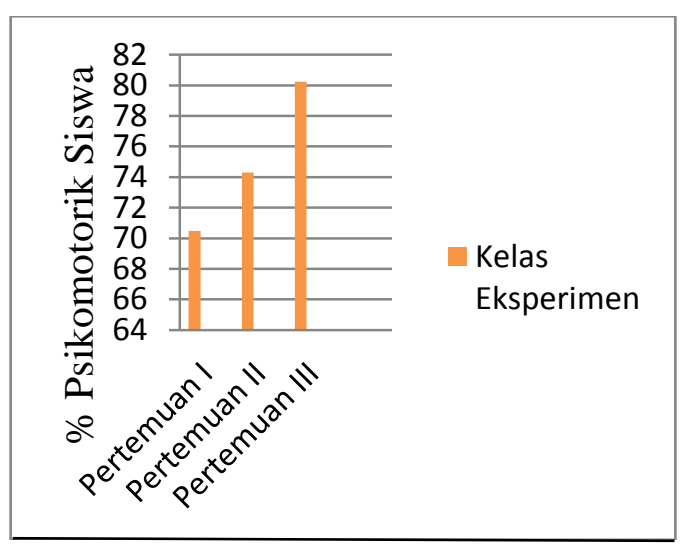

Gambar3. Penilaian Psikomotorik Siswa di Kelas Eksperimen

Gambar

menunjukkanperkembangan

psikomotorik siswadi kelas eksperimen selama mendapat perlakuan dengan menggunakan model pembelajaraninquiry training berbantuan macromediaflash.

Presentase nilai psikomotorik siswa daripertemuanI, II dan III masingmasing $70,48 \%, 74,29 \%$ dan $80,24 \%$. Dengan kata lain, presentase nilai rata-rata psikomotorik siswa selama pembelajaran di kelas eksperimen adalah $75,003 \%$ dengan kriteria aktif.

\section{Pembahasan Penelitian}

Berdasarkan hasil penelitian yang dilakukan setelah kedua kelas diberi perlakuan yang berbeda yaitu pada kelas eksperimen menggunakan model pembelajaran inquiry training berbantuan macromediaflash dan pada kelas kontrol menggunakan pembelajaran konvensional., masingmasing kelas diberi postes untuk melihat adanya perbedaan akibat diberikan perlakuan pembelajaran yang berbeda. Dari data postes kedua kelas diperoleh nilai rata-rata postes untuk kelas eksperimen sebesar 73,57 dan nilai rata-rata postes kelas kontrol sebesar 63. Hasil uji normalitas dan homogenitas untuk kedua sampel diperoleh bahwa nilai postes berdistribusi normal dan berasal dari populasi yang homogen. Hasil uji hipotesis untuk postes menggunakan uji t diperoleh $t_{\text {hitung }}>$ $t_{\text {tabel }}(4,065>1,669)$ yang berarti bahwa terdapat perbedaan akibat pengaruh penerapan model pembelajaran Inquiry Training berbantuan macromediaflash terhadap hasil belajar siswa pada materi pokok Fluida Statis di kelas XI SMA Negri 10 Medan T.P. 2014/2015.

Peningkatan aktivitas pada . kelas eksperimen juga lebih tinggi daripada kelas kontrol yaitu pada kelas eksperimen pada pertemuan III dan pertemuan II-III masingmasing $17 \%$ dan $35 \%$ sedangkan kelas kontrol pada pertemuan I-II dan pertemuan II-III masing-masing $12,7 \%$ dan $19,7 \%$. Peningkatan afektif siswa juga pada kedua kelas dalam kegiatan belajar mengajar juga cenderung berbeda. Pada kelas eksperimen perkembangan afektif siswa pada tiap pertemuan lebih tinggi yaitu pada pertemuan I,II dan III masingmasing $59,76 \%, \quad 65,48 \%$ dan $73,10 \%$ dengan kategori aktif sedangkan pada kelas kontrol perkembangan peningkatan sikap siswa adalah 55\%, $62,14 \%$ dan $69,76 \%$ dengan kategori cukup aktif.

Adanya pengaruhmodel pembelajaran inquiry training terhadap hasil belajar siswa dikarenakan dalam model pembelajaran inquiry trainingsiswa dilibatkan langsung dalam pembelajaran, sehingga siswa menjadi aktif dan kemampuan berpikir siswa dilatih untuk mencari, menyelidiki dan menganalisis pemecahan masalah.

Penelitian ini juga diperkuat dengan melakukan eksperimen, sehingga pembelajaran dalam 
penelitian ini dapat memadukan beberapa keterampilan memproseske dalam suatu unit pengalaman yang bermakna. Keterampilan siswa dalampembelajaran dengan menggunakan model pembelajaran inquiry trainingmengajarkan siswa untuk belajar memverifikasi, mengumpulkan data eksperimentasi, dan mengolah serta menemukan jawaban permasalahan pada saat siswa bekerja bersama kelompok dengan mengemukakan hipotesis mereka dan pada saat siswa bertanya kepada guru serta pada saat siswa mengemukakan pendapat atau mengemukakan apa yang telah mereka lihat dan kemudian membuktikannya melalui pengumpulan data saat bereksperimen. Selain itu, penelitimemberikan Lembar Kerja Siswa (LKS) yang relevan dengan kehidupan sehari-hari sehingga siswa lebih mudah mengerjakannya dan membuat rencana pelaksanaan pembelajaran (RPP) agar proses dan tahap pembelajaran tersusun secara sistematis dan diharapkan hasil belajar siswa akan lebih baik.

Keadaan di atas sejalan dengan beberapa hasil penelitian terdahulu yang menggunakan model pembelajaran inquiry training, diantaranyaHarahap dan Sinuraya (2013)diperolehnilai rata-rata pretes kelas eksperimen sebesar 34,87 dan nilai rata-rata postes sebesar 70,37. Pada kelas kontroldiperoleh nilai rata-rata pretes siswa sebesar 33,5 dan nilai rata-rata postes sebesar 63,12. Aktivitas siswa selama mengikuti pembelajaran dengan menggunakan model pembelajaran inquiry trainingpada materi pokok Suhu dan Pengukuran diperoleh skor rata-rata aktivitas siswa mencapai 67,38 dengan kategori aktif.
Berdasarkan penelitian ini, dengan memberikanmodel pembelajaran inquiry trainingsiswa lebih mudah menguasai konsep fluida statisyang terdapat dalam kehidupan sehari-hari sehingga dapat meningkatkan hasil belajar dan aktivitas siswa.

\section{KESIMPULAN DAN SARAN \\ Kesimpulan}

Berdasarkan hasil penelitian yang diperoleh dari analisis data dan pengujian hipotesis maka dapat disimpulkan seagai berikut: nilai rata-rata hasil belajar siswa pada kelas eksperimen dan kelas kontrol masing-masing 73,57 dan 63 . Peningkatan aktivitas belajar siswa di kelas eksperimen dan kontrol selama mengikuti pembelajaran masing-masing dengan persentase $\mathrm{N}$ Gain aktivitas pertemuan I dan pertemuan II $=17 \%$, pertemuan II dan pertemuan III $=35 \%$ dengan peningkatan aktivitas kategori sedang, dan pertemuan I dan pertemuan II $=12,7 \%$, pertemuan II dan III $=19,7 \%$ yang merupakan peningkatan aktivitas kategori rendah serta terdapat perbedaan yang signifikan akibat pengaruh model pembelajaran inquiry training berbantuan macromediaflash terhadap hasil belajar siswa.

\section{Saran}

Berdasarkan hasil dan kesimpulan dalam penelitian ini, maka peneliti mempunyai beberapa saran, yaitu: bagi peneliti selanjutnya sebelummelakukan pembelajaran, terlebih dahulu peneliti menjelaskan langkah-langkah model pembelajaran inquiry training berbantuan macromediaflash agar siswa tidak kebingungan untuk mengikuti fase pembelajaran, kepada guru yang 
ingin menggunakan model Uno, H., (2008), Model Pembelajaran, pembelajaran inquiry training Bumi Aksara, Jakarta.

berbantuan macromediaflash supaya mempersiapkan masalah-masalah dalam keidupan sehari-hari yang lebih menarik dan berhubungan dengan materi pelajaran yang dipelajari sehingga siswa akan tertarik mengikuti pelajaran

\section{DAFTAR PUSTAKA}

Harahap, F., dan Sinuraya, J., (2013),

Pengaruh

Model

Pembelajaran

Inquiry

Trainingterhadap

Hasil

Belajar Siswa pada Materi

Pokok Suhu dan Pengukuran

Kelas VII Semester I MTs N 2

Medan T.P. 2012/2013, Jurnal

Inpafi, Hal 34-40.

Joyce, B.,Weil, M., dan Calhoun, E., (2009), Models of Teaching (Model-Model Pengajaran), Pustaka Pelajar, Yogyakarta.

Kunandar, (2007), Guru Profesional, Rajawali Pers, Jakarta.

Panjaitan, M. D. C.,(2015),Studi Pendahuluan,tidak dipublikasikan

Simanjuntak, S. M., (2014), Pengaruh Model Pembelajaran Kooperatif Tipe Group Investigation (GI) Berbantuan Media Komputer terhadap Hasil Belajar Siswa pada Materi Pokok Listrik Dinamis di Kelas X Semester II SMA Negeri 10 Medan T.A. 2013/2014, Skripsi, FMIPA, Unimed, Medan.

Slameto, (2010), Belajar dan FaktorFaktor yang Mempengaruhinya, Rineka Cipta, Jakarta.

Trianto, (2011), Mendesain Model Pembelajaran Inovatif Progresif,Kencana, Jakarta. 